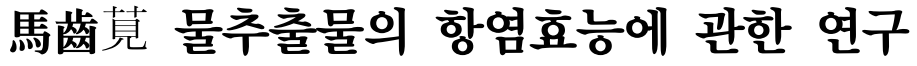

\author{
주재공 ${ }^{1 \#}$, 한효상 ${ }^{2}$, 이영종 ${ }^{*}$ \\ 1 : 가천대학교, 2 : 중부대학교
}

\section{Anti-inflammatory Effect of Portulacae Herba Water Extract on Lipopolysaccharide-activated RAW 264.7 Macrophages}

\author{
Jai-Kong Joo ${ }^{1 \#}$, Hyo-Sang $\mathrm{Han}^{2}$, Young-Jong Lee ${ }^{1^{*}}$ \\ 1 : Department of Herbology, College of Oriental Medicine, Gachon University Seongnam 13120, Korea \\ 2 : Department of Health Administration, College of Social Sciences, Joongbu University Geumsan 32713, Korea
}

\begin{abstract}
Objectives : The present study aimed to investigate the anti-inflammatory effects of the water extracts of Portulacae Herba (PH).

Methods : We measured the effects of the water extracts of Portulacae Herba (PH) on the cell viability of mouse macrophage RAW 264.7 cells, the intracellular calcium production, and the proinflammatory mediators including nitric oxide (NO), vascular endothelial growth factor (VEGF), platelet-derived growth factor (PDGF)-BB, which are induced by the lipopolysaccharides (LPS), and obtained the results shown below.

Results : After the cultivation of the PH extracts along with the mouse macrophages, the cell survival rate did not decrease with the MTT assay. However, the PH extracts did significantly suppress the production of NO by the mouse macrophages induced by LPS at the concentrations of 25,50 and $100 \mu \mathrm{g} / \mathrm{mL}$. The PH extract also significantly suppressed the VEGF, PDGF-BB and intracellular calcium production of the mouse macrophages by LPS at concentrations of 25, 50 and $100 \mu \mathrm{g} / \mathrm{mL}$. As shown in the results above, the PH extracts do not have a toxic effect on the macrophages, but still have an anti-inflammatory effect that significantly reduces the intracellular calcium production as well as the production of NO, VEGF and PDGF-BB at concentrations above $25 \mu \mathrm{g} / \mathrm{mL}$.

Conclusions : In conclusion, the inhibitory anti-inflammatory effects of the PH extract can be used for a new treatment of anti-inflammatory diseases.
\end{abstract}

Key words : Portulacae Herba, macrophages, inflammation, proinflammatory mediators, cytokine

\section{서 론}

馬齒莧은 『新修本草』 ${ }^{1)}$ 에 "莧實, 味甘, 寒 大寒, 無毒. 主

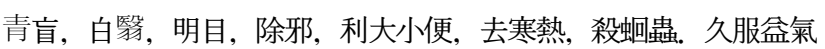
力, 不飢輕身. 一名馬莧, 一名莫實, 細莧亦同. 生淮陽 川澤及 田中, 葉如藍, 十一月採."로 처음 수재되었고 淸熱解毒, 凉血 止血, 止痢, 消腫의 효능이 있어 熱毒瀉痢, 熱淋, 尿閉, 赤白 帶下, 崩漏, 痔血, 疮瘍痛疗, 丹毒, 㾮症, 濕癬, 白秃 등의 증상을 치료하는데 상용되고 있다 ${ }^{2)}$.
馬齒莧의 기원식물은 『대한민국약전외한약(생약)규격집』 3), 『북한약전』 ${ }^{4)}$, 中華人民共和國藥典』 ${ }^{5)}$ 에는 모두 쇠비름 Portolaca oleracea L. 의 전초로 동일하게 收載되어 있다.

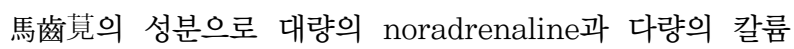
염이 함유되어 있으며 ${ }^{6)}$, 아미노산으로서 alanine, aspartic acid 등이 있으며, 다당체로는 glucose, fructose, sucrose 가 있고, 유기산과 지방산으로 malic acid, oxalic acid, citric acid, glutamic acid, asparic acid, alanine 등이 보 고 되었으며 ${ }^{7)}$, sterol로는 stigmasterol, campesterol이 있

\footnotetext{
*Corresponding author : Young-Jong Lee. Department of Herbology, College of Oriental Medicine, Gachon University Seongnam 13120, Korea - Tel : +82-31-750-5415 · E-mail : garak@gachon.ac.kr

\#First author : Jai-Kong Joo. Department of Herbology, College of Oriental Medicine, Gachon University Seongnam 13120, Korea

- Tel : +82-31-750-5415 • E-mail : atom1223@naver.com

- Received : 22 October 2015 - Revised : 02 December 2015 · Accepted : 14 January 2016
} 
$ㄱ ㅗ^{8)}$, vitamin $\mathrm{B}_{1}$ 및 $\mathrm{C}$, saponin, tannin, flavonoid 등이 보고 되어 있다 ${ }^{9)}$.

馬齒莧의 약리작용으로는 자궁평활근 수축작용과 장관연동 운동 촉진작용 ${ }^{7)}$, 항균작용 ${ }^{10)}$, 항진균작용 ${ }^{11}$, 항산화작용 ${ }^{12)}$, 항염작용 ${ }^{13,14)}$ 등이 보고되었고, 또 간질환개선, 이뇨 및 항부 종에 효과가 있으며 ${ }^{15)}$, 세포성 및 체액성 면역반응에 있어서 과민반응을 억제하는 것으로 보고되었다 ${ }^{16)}$.

馬英莧은 한의학에서 清熱解毒의 효능으로 각종 염증 질환 에 사용되고 있는데, 馬齒莧의 항염효능으로는 위손상에 대한 보호적인 항산화, 항염효과가 보고되었고 ${ }^{13)}$, 또 염증매개물질 인 $\mathrm{PGE}_{2}$ 의 생성과 $\mathrm{PGE}_{2}$ 를 생성하는데 관련된 $\mathrm{COX}-2$ 단백 질의 발현을 억제하는 것 ${ }^{14)}$ 등이 보고되었다. 그러나 馬茼莧 이 대식세포에 관여한 염증촉발인자들이 항염활성에 미치는 영향에 관한 연구는 아직 보고되지 않았다. 이에 저자는 馬齒 莧이 항염활성에 미치는 효과를 검증해보고자 馬齒莧을 물추 출하여 제조한 시료(PH; Portulacae Herba)를 대상으로 mouse macrophage RAW 264.7 cells의 세포생존율(cell viability)과 lipopolysaccharide(LPS)로 유발된 RAW 264.7 cells의 nitric oxide(NO), vascular endothelial growth factor(VEGF), platelet derived growth factor (PDGF)-BB, keratinocyte -derived chemokine $(\mathrm{KC})$ 등의 염증촉발인자(proinflammatory mediators)와 세포내 칼슘의 생성 증가에 미치는 영향을 조 사하여 유의한 결과를 얻었기에 보고하는 바이다.

\section{재료 및 방법}

\section{1. 재료}

1) 약재

실험에 사용된 馬蓖莧 (Portulacae Herba)은 옴니허브 제 약회사 (대구, 한국)로부터 구입하여 가천대학교 한의과대학 본초학교실에서 검정하였다 (No; 2010-04-002). 모든 약재 는 실험 전에 초음파 세척기 (Branson, USA)를 이용하여 불 순물을 제거하고 사용하였다.

\section{2) Cell line}

실험에 사용된 대식세포는 mouse macrophage (Raw 264.7 cells)이며 한국 세포주 은행 (KCLB, Korea)에서 구입 하였다.

\section{3) 시약 및 기기}

(1) 시약

본 실험을 위해서 LPS(Sigma, USA), ethyl alcohol (Samchun Chemical, Korea), DMSO(Sigma, USA), DMEM (Sigma, USA), $1 \times$ PBS(Sigma, USA), EDTA(Sigma, USA), isopropanol(Sigma, USA), trypsin-EDTA(Sigma, USA), Bio-Plex Cytokine assay kit(Bio-Rad, USA), Procarta Cytokine assay kit(Panomics, USA) 등이 사용되었다.

(2) 기기

본 실험에 사용된 기기는 $\mathrm{CO}_{2}$ incubator(Nuaire, USA), rotary vacuum evaporator(Eyela, Japan), air compressor
(Tamiya, Japan), homogenizer (Omni, USA), research microscope(Becton dickinson, USA), refrigerated centrifuge (Hanil, Korea), high-speed microcentrifuge(Zyrogen, Korea), personal microcentrifuge(Mylab, Korea), fume hood(Hanil, Korea), clean bench(Jeio thec, Korea), ultrasonic cleaner (Branson, USA), microplate reader 680(Bio-Rad, USA), vortex mixer(Vision Scientific Co, Korea), multi-channel pipette(Bio-Rad, USA), water bath(Saehan Co, Korea), ice-maker(Vision Scientific Co, Korea), bio-plex 200 (Bio-Rad, USA), vacuum filtration system(Millipore, USA), micromixer Mx2(FINEPCR, Korea), thermo micromixer (FINEPCR, Korea), thermo bath(FINEPCR, Korea), liquid nitrogen tank(CHART/MVE, USA), deep freezer(Ilshin Lab Co, Korea), vacuum freezing drier(Eyela, Japan), TRIAD LT spectrofluorometer (Dynex, USA) 등이다.

\section{2. 방 법}

1) 시료의 제조

(1) 馬齒莧 추출물 제조

馬蔥莫 $50 \mathrm{~g}$ 을 정확하게 측정한 뒤 환류추출기에 1 차 증 류수 $2,000 \mathrm{~mL}$ 와 함께 넣은 뒤 탕액이 끓는 시점으로부터 2 시간 동안 가열하여 추출한 다음 추출액을 filter paper (Advantec No.2, Japan)를 사용하여 감압 여과한 여과액을 rotary vacuum evaporator를 이용하여 농축액을 얻었다. 이 농축액을 동결건조기를 이용하여 건조시켜서 얻은 분말을 시료로 사용하였다. 동결건조 추출물은 $14.2 \mathrm{~g}$ 을 얻었으며, 수율은 $28.4 \%$ 였다.

\section{2) 세포배양}

Raw 264.7 cells은 $37{ }^{\circ} \mathrm{C}, 5 \% \mathrm{CO}_{2}$ 조건에서 $10 \% \mathrm{FBS}$, penicillin $(100 \mu \mathrm{g} / \mathrm{mL})$, streptomycin $(100 \mu \mathrm{g} / \mathrm{mL})$ 이 첨가된 DMEM 배지로 배양되었다. Cells은 $75 \mathrm{~cm}^{2}$ flask (Falcon, $\mathrm{USA}$ )에서 충분히 증식된 후 배양 3 일 간격으로 배양세포 표면을 phosphate buffered saline (PBS) 용액으로 씻어준 후 $50 \mathrm{~mL}$ flask 당 $1 \mathrm{~mL}$ 의 $0.25 \%$ trypsin-EDTA 용액을 넣고 실온에서 1 분간 처리한 다음 trypsin용액을 버리고 37 ${ }^{\circ} \mathrm{C}$ 에서 5 분간 보관하여 세포를 탈착하여 계대 배양하였다. 탈착된 세포를 $10 \% \mathrm{FBS}$ 가 첨가된 $\mathrm{DMEM}$ 배양액 $10 \mathrm{~mL}$ 에 부유시킨 다음 새로운 배양용기 $(50 \mathrm{~mL}$ culture flask)에 옮 겨 1 : 2 의 split ratio로 $\mathrm{CO}_{2}$ 배양기 $\left(37{ }^{\circ} \mathrm{C}, 5 \% \mathrm{CO}_{2}\right)$ 에서 배양하였다.

\section{3) 세포독성 검사}

준비된 시료가 RAW 264.7 cells에 나타내는 세포독성 유 발 효과를 알아보기 위하여 MTT assay ${ }^{17}$ 를 실시하였다. 96 well plate에 $1 \times 10^{4}$ cells/well의 cell을 $100 \mu$ l씩 넣고 3 $7^{\circ} \mathrm{C}, 5 \% \mathrm{CO}_{2}$ incubator에서 24 시간 동안 배양한 후 배지 를 버리고 배양세포 표면을 phosphate buffered saline $(1 \times$ $\mathrm{PBS})$ 용액으로 씻어주었다. 같은 양의 배지와 $\mathrm{PBS}$ 에 녹인 시료 $(25,50,100,200 \mathrm{\mu g} / \mathrm{mL})$ 를 각 well에 처리하고 24 시간 동안 배양하였다. 배양이 끝난 후 $\mathrm{PBS}$ 에 녹인 $1 \mathrm{mg} / \mathrm{mL}$ 
MTT (Sigma, USA)를 $100 \mu \ell$ 씩 각 well에 처리하여 알루미 늄호일로 차광시킨 후 2 시간 동안 같은 조건에서 배양하였다. 배양액을 모두 제거한 후 $\mathrm{DMSO}$ 를 $100 \mu \mathrm{l}$ 처리하고 $37{ }^{\circ} \mathrm{C}$ 에서 2 시간 방치한 후 microplate reader (Molecular Devices, $\mathrm{USA}$ )를 이용하여 $540 \mathrm{~nm}$ 에서 흡광도를 측정하여 세포생존 율을 비교하였다. Cell viability는 다음 공식으로 계산되었다.

Cell viability $(\%)=A T / A C \times 100$

$\mathrm{AC}$ : absorbance of control

AT : absorbance of extract solution tested

\section{4) 일산화질소(Nitric oxide) 생성측정}

Weissman 등 ${ }^{18)}$ 의 방법을 참조하여 다음과 같이 실험하였 다. $\mathrm{LPS}$ 를 단독처리 $(1 \mu \mathrm{g} / \mathrm{mL})$ 하거나 혹은 다양한 농도의 시 료 $(25,50,100 \mu \mathrm{g} / \mathrm{mL})$ 와 함께 배지에 담아 각 well에 처리 하고 24 시간 동안 $37{ }^{\circ} \mathrm{C}, 5 \% \mathrm{CO}_{2}$ incubator에서 배양한 후 세포배양 상등액 $100 \mu \ell$ 를 채취하여 여기에 그리스 시약 100 $\mu \ell$ 를 혼합하여 15 분 동안 반응시킨 후 Microplate Reader (Bio-Rad, USA)를 이용하여 $540 \mathrm{~nm}$ 에서 흡광도를 측정하 였다. 세포의 NO 생성은 다음 공식으로 계산하였다.

Productions of Nitric oxide(\%) $=$ AT $/$ AC $\times 100$

AC : absorbance of control

AT : absorbance of extract solution tested

\section{5) 사이토카인(Cytokine) 분비 측정}

사이토카인 분비와 관련된 시료의 영향을 알아보기 위해 Politch 등 ${ }^{19)}$ 의 방법을 응용하여 Bio-Plex $\mathrm{Pro}^{\mathrm{TM}}$ Mouse Cytokine, Chemokine, and Growth Factor Assay kit ( $\mathrm{Bio}-\mathrm{Rad}$ )를 다음과 같이 시행하였다. 96 well plate에 $1 \times$ $10^{5}$ cells $/ \mathrm{mL}$ 의 cell을 $100 \mu l$ 씩 넣고 $37^{\circ} \mathrm{C}, 5 \% \quad \mathrm{CO}_{2}$ incubator에서 24 시간 동안 배양한 후 배지를 버리고 배양 세포 표면을 $1 \times \mathrm{PBS}$ 용액으로 씻어준 뒤 각 well에 LPS를 단독처리 $(1 \mu \mathrm{g} / \mathrm{mL})$ 하거나 혹은 다양한 농도의 시료 $(25,50$, $100 \mathrm{\mu g} / \mathrm{mL}$ )와 함께 배지에 담아 처리하고 24 시간 동안 배양 하였다. 배양이 끝나면 상등액(cell culture supernatant)을 채취하여 filter plate(96 well type)에 미리 준비되어 있던 antibody-conjugated capture beads와 결합시킨다. 결합된 capture beads가 담긴 filter plate의 각 well을 $150 \mu \mathrm{l}$ 의 wash buffer로 세척한다. 세척이 끝난 뒤 각 well에 detection antibody를 추가한 후 30 분간 배양한다. 배양이 끝나면 wash buffer로 3회 세척한 뒤 각 well에 streptavidin-PE 를 분주하고 상온에서 $300 \sim 500 \mathrm{rpm}$ 의 조건으로 30 분간 진 동배양한다. 배양이 끝나면 wash buffer로 3 회 세척한 뒤 각 well에 $120 \mu l$ 의 reading buffer를 분주하고 상온에서 300 $500 \mathrm{rpm}$ 의 조건으로 5 분간 진동배양한 후 bio-plex array reader (Bio-Plex 200)을 이용, 측정코자 하는 사이 토카인류(VEGF, $\mathrm{PDGF}-\mathrm{BB}, \mathrm{KC}$ 등)의 발현에 대한 시료의 영향을 계산, 비교하였다.

\section{6) 세포내 calcium 생성측정}

대식세포내 칼슘의 생성과 관련된 시료의 영향을 알아보기 위해 Paredes 등 ${ }^{20}$ 의 방법을 참조하여 다음과 같이 실험을 시행하였다. 96 well plate에 $1 \times 10^{5}$ cells $/ \mathrm{mL}$ 의 cell을 100 $\mu l$ 씩 넣고 $37{ }^{\circ} \mathrm{C}, 5 \% \mathrm{CO}_{2}$ incubator에서 24 시간 동안 배 양한 후 배지를 버리고 배양세포 표면을 $1 \times \mathrm{PBS}$ 용액으로 씻어준 뒤 각 well에 LPS를 단독처리 $(1 \mu \mathrm{g} / \mathrm{mL})$ 하거나 혹은 다양한 농도의 시료 $(25,50,100 \mu \mathrm{g} / \mathrm{mL})$ 와 함께 배지에 담아 처리하고 24 시간 동안 $37{ }^{\circ} \mathrm{C}, 5 \% \mathrm{CO}_{2}$ incubator에서 배양 하였다. 배양이 끝나면 배양액을 제거하고 Fluo-4 dye loading solution을 30 분간 $37{ }^{\circ} \mathrm{C}$ 에서 처리하고, 상온에서 30 분간 배양한 후 spectrofluorometer(TRIAD LT)를 이용 하여 (excitation $485 \mathrm{~nm}$; emission $535 \mathrm{~nm}$ ) 생성량을 측정, 비교하였다.

\section{3. 통계처리}

본 실험에서 얻은 결과는 평균치 \pm 표준오차(mean \pm $\mathrm{SEM})$ 로 나타내었으며, 대조군과 각 실험군의 평균의 차이는 One-way ANOVA와 Dunnett의 사후검정법을 이용하여 $p$-value 값이 0.05 미만일 때 통계적으로 유의한 차이가 있 는 것으로 판정하였다.

\section{결 과}

\section{1. 세포 생존율}

$\mathrm{PH}$ 가 대식세포의 세포 생존율에 미치는 영향을 알아보기 위하여 $\mathrm{PH}$ 를 24 시간 처리한 결과 $25 \mu \mathrm{g} / \mathrm{mL}$ 이상의 모든 농도에서 유의한 감소는 없었다(Fig. 1).

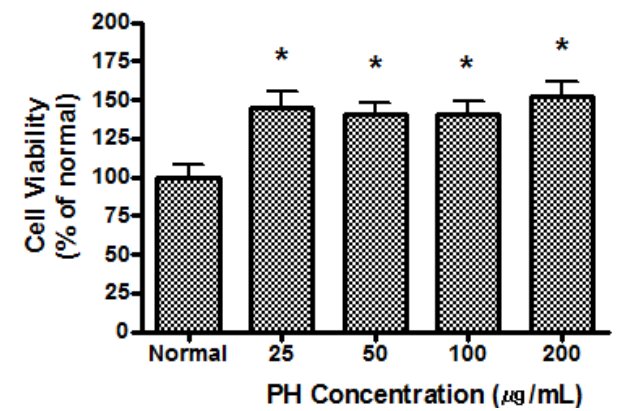

Fig. 1. Effect of PH on cell viability in RAW 264.7 cells for 24 hrs incubation.

$\mathrm{PH}$ : Water extract of Portulacae Herba. Cells were incubated for 24 hrs. Results are represented as mean \pm SD of more than three independent experiments.

Normal : Not treated with $\mathrm{PH}$.

* represents $p<0.05$ compared to the normal.

\section{NO 생성 증가에 대한 효과}

$\mathrm{PH}$ 가 LPS로 유발된 마우스 대식세포의 NO 생성증가에 대한 효과를 알아보기 위하여 $\operatorname{LPS}(1 \mathrm{ug} / \mathrm{mL})$ 와 함께 $\mathrm{PH}$ 를 24 시간 동안 처리한 결과 $25 \mu \mathrm{g} / \mathrm{mL}$ 이상의 모든 농도에서 $\mathrm{LPS}$ 에 의한 $\mathrm{NO}$ 생성증가를 유의하게 $(P<0.05)$ 억제시켰다 (Fig. 2). 


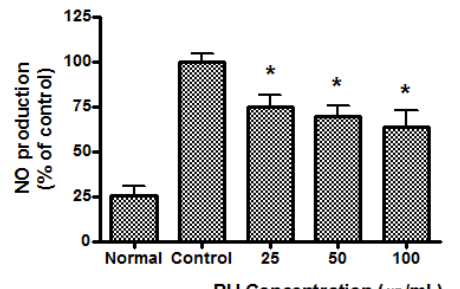

Fig. 2. Effect of $\mathrm{PH}$ on $\mathrm{NO}$ production in RAW 264.7 cells treated with LPS for $24 \mathrm{hrs}$.

$\mathrm{PH}$ : Water extract of Portulacae Herba. Cells were incubated for 24 hrs. Results are represented as mean \pm SD of more than three independent experiments.

Normal : Not treated with $\mathrm{PH}$.

Control : Treated with LPS $(1 \mu \mathrm{g} / \mathrm{mL})$ only.

* represents $p<0.05$ compared to the control.

\section{Cytokine 생성에 대한 영향}

\section{1) VEGF 생성에 대한 영향}

$\mathrm{PH}$ 가 LPS로 유발된 마우스 대식세포의 VEGF 생성 증가에 미치는 영향을 알아보기 위하여 $\mathrm{LPS}(1 \mathrm{ug} / \mathrm{mL})$ 와 함께 $\mathrm{PH}$ 를 24 시간 동안 처리한 결과 $25 \mu \mathrm{g} / \mathrm{mL}$ 이상의 모든 농도에서 LPS에 의한 VEGF 생성 증가를 유의하게 억제시켰다(Fig. 3).

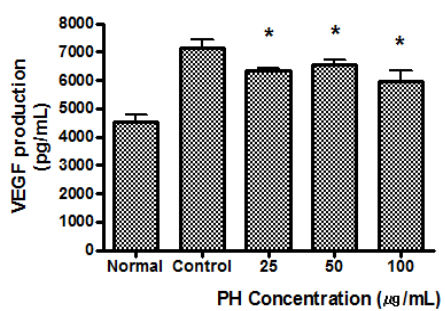

Fig. 3. Effect of $P H$ on VEGF production in RAW 264.7 cells treated with LPS for $24 \mathrm{hrs}$.

$\mathrm{PH}$ : Water extract of Portulacae Herba. Cells were incubated for $24 \mathrm{hrs}$. Results are represented as mean $\pm \mathrm{SD}$ of more than three independent experiments.

Normal : Not treated with $\mathrm{PH}$.

Control : Treated with LPS $(1 \mu \mathrm{g} / \mathrm{mL})$ only.

* represents $p<0.05$ compared to the control.

\section{2) PDGF-BB 생성에 대한 영향}

$\mathrm{PH}$ 가 LPS로 유발된 마우스 대식세포의 $\mathrm{PDGF}-\mathrm{BB}$ 생성 증가에 미치는 영향을 알아보기 위하여 $\operatorname{LPS}(1 \mathrm{ug} / \mathrm{mL})$ 와 함 께 $\mathrm{PH}$ 를 24 시간 동안 처리한 결과 $25 \mu \mathrm{g} / \mathrm{mL}$ 이상의 모든 농도에서 LPS에 의한 $\mathrm{PDGF}-\mathrm{BB}$ 생성 증가를 유의하게 억제 시켰다(Fig. 4).

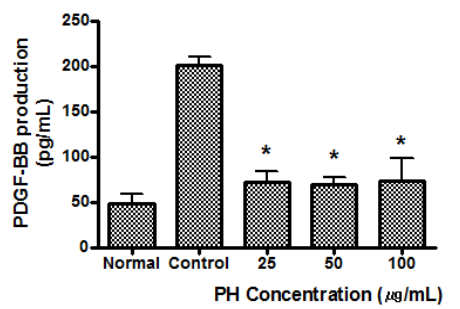

Fig. 4. Effect of PH on PDGF-BB production in RAW 264.7 cells treated with LPS for $24 \mathrm{hrs}$.

$\mathrm{PH}$ : Water extract of Portulacae Herba. Cells were incubated for $24 \mathrm{hrs}$. Results are represented as mean \pm SD of more than three independent experiments.

Normal : Not treated with $\mathrm{PH}$.

Control : Treated with LPS $(1 \mu \mathrm{g} / \mathrm{mL})$ only.

* represents $\mathrm{p}<0.05$ compared to the control.

\section{3) $\mathrm{KC}$ 생성에 대한 영향}

$\mathrm{PH}$ 가 LPS로 유발된 마우스 대식세포의 $\mathrm{KC}$ 생성 증가에 미치는 영향을 알아보기 위하여 $\mathrm{LPS}(1 \mathrm{ug} / \mathrm{mL})$ 와 함께 $\mathrm{PH}$ 를 24 시간 동안 처리한 결과 유의한 변화는 나타나지 않았다 (Fig. 5).

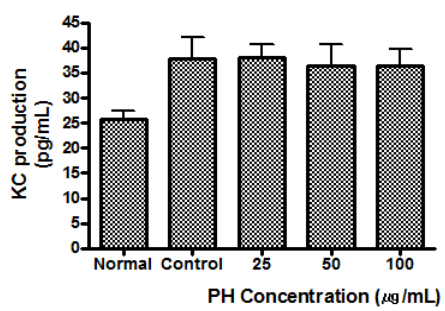

Fig. 5. Effect of $\mathrm{PH}$ on $\mathrm{KC}$ production in RAW 264.7 cells treated with LPS for $24 \mathrm{hrs}$.

$\mathrm{PH}$ : Water extract of Portulacae Herba. Cells were incubated for 24 hrs. Results are represented as mean \pm SD of more than three independent experiments.

Normal : Not treated with $\mathrm{PH}$.

Control : Treated with LPS $(1 \mu \mathrm{g} / \mathrm{mL})$ only.

* represents $p<0.05$ compared to the control.

\section{4) 세포내 calcium 생성에 대한 영향}

$\mathrm{PH}$ 가 LPS로 유발된 마우스 대식세포의 세포내 calcium 생성 증가에 미치는 영향을 알아보기 위하여 $\mathrm{LPS}(1 \mathrm{ug} / \mathrm{mL})$ 와 함께 $\mathrm{PH}$ 를 24 시간 동안 처리한 결과 $25 \mu \mathrm{g} / \mathrm{mL}$ 이상의 모든 농도에서 LPS에 의한 세포내 calcium 생성 증가를 유 의하게 $(P<0.05)$ 억제시켰다(Fig. 6).

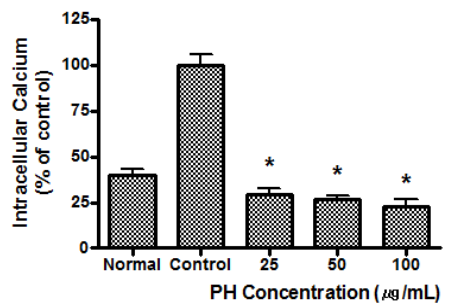

Fig. 6. Effect of $\mathrm{PH}$ on intracellular calcium production in RAW 264.7 cells treated with LPS for $24 \mathrm{hrs}$.

$\mathrm{PH}$ : Water extract of Portulacae Herba. Cells were incubated for 24 hrs. Results are represented as mean \pm SD of more than three independent experiments.

Normal : Not treated with $\mathrm{PH}$

Control : Treated with LPS (1 $\mu \mathrm{g} / \mathrm{mL})$ only.

* represents $\mathrm{p}<0.05$ compared to the control.

\section{고 찰}

馬齒莧은 『食療本草』 ${ }^{21}$ 에는 "圭馬毒疮, 以水募, 冷服一

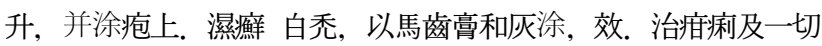
風, 傅杖狍良."라고 하였으며, 『本草拾遺』 ${ }^{22}$ 에는 "止消渴"이 라 하였고, 「本草圖經」 ${ }^{23}$ 에는 "能肥腸, 令人不思食耳. 古方 治女人赤白下多用之."라 수재되었고, ${ }^{\mathbb{2}}$ 本草綱目」 ${ }^{24)}$ 에서는 " 散血散腫, 利腸滑胎, 解毒通淋, 治產後虛汗."이라 하였으며, “東醫寶鑑」 ${ }^{25}$ 에서는 "性寒味酸無毒. 主諸腫惡痏, 利大小便, 破権結, 療金瘡內漏, 止渴, 殺諸蟲. (本草)"이라 하였다. 이처 럼 한의학에서 馬齒莧은 清熱解毒, 凉血止痢, 除濕通淋의 효 능이 있어 熱毒瀉麻, 熱痳, 尿閉, 赤白帶下, 崩漏, 痔血, 疮瘍 
痛疤, 丹毒, 瘦㾟, 濕癬, 白秃 등의 증상을 치료하는데 많이 사용되고 있다 ${ }^{2)}$.

馬齒莧의 약리작용으로는 임 등 ${ }^{15)}$ 은 馬齒莧추출물이 간질 환개선, 이뇨 및 항부종에 효과있음을 보고하였고, 오 $^{16)}$ 는 馬 齒莧이 세포성 및 체액성 면역반응에 있어서 과민반응을 억제 하는 것을 보고하였다. 또 馬齒莧의 항염작용에 관해서 김 ${ }^{13)}$ 은 염산-에탄올에 의해 유발된 위손상에 대한 항산화, 항염 효과를 가지고 있는 것을 확인하였다. 또 강 ${ }^{14)}$ 은 馬齒莧의 메 탄올추출물이 염증매개물질인 $\mathrm{PGE}$ 의 생성과 $\mathrm{PGE}_{2}$ 를 생성 하는데 관련된 $\mathrm{COX}-2$ 단백질의 발현을 억제하는 것을 밝혀 내었다. 이에 저자는 馬齒莧으로 염증촉발인자들의 항염활 성에 미치는 영향을 알아보기 위해, 馬齒莧을 물추출하여 제 조한 시료를 대상으로 mouse macrophage RAW 264.7의 세포생존율, 그리고 LPS에 의해서 유발되는 RAW 264.7의 $\mathrm{NO}, \mathrm{VEGF}, \mathrm{PDGF}-\mathrm{BB}, \mathrm{KC}$ 등과 같은 염증촉발인자 (proinflammatory mediator), 세포내 칼슘의 생성 증가에 미치는 효과를 조사하였다.

본 연구에서는 $\mathrm{PH}$ 가 macrophage의 세포 생존율에 미치 는 영향을 비교하기 위해 24 시간 동안 처리한 결과 25,50 , $100,200 \mu \mathrm{g} / \mathrm{mL}$ 의 농도까지 유의한 생존율 감소는 나타나지 않았으며, 이러한 결과를 바탕으로 항염효능 실험을 25,50 , $100 \mathrm{\mu g} / \mathrm{mL}$ 의 농도로 진행하였다.

$\mathrm{NO}$ (nitric oxide)는 질소 중간 대사물 중 하나로 면역전달 물질인 cytokine의 영향으로 면역세포로부터 생산되어, 염증 반응부위에 유리됨으로써 $\mathrm{Fe}-\mathrm{S}$ 를 함유하는 효소의 작용을 억 제시키거나 DNA에 손상을 미쳐 항미생물작용이나 항암작용을 한다고 알려졌다. 또한 2, 2'-Azobis (2-amidinopropane) dihydrochloride(AAPH)에 의한 세포손상과 관련하여, NO는 맥관계(vascular system)에서 내피유래 확장인자(endothelium -derived relaxation factor)로서 작용하며 ${ }^{26)}$, 혈소판응집 (platelet aggregation)과정에 관여한다 ${ }^{27)}$.

본 연구에서 $\mathrm{PH}$ 가 LPS로 유발된 마우스 대식세포의 $\mathrm{NO}$ 생성 증가에 미치는 영향을 비교하기위해 24 시간 동안 처리 한 결과 $25 \mu \mathrm{g} / \mathrm{mL}$ 이상의 모든 농도에서 LPS에 의한 $\mathrm{NO}$ 생성 증가를 유의하게 억제시켰다.

VEGF(Vascular endothelial growth factor)는 암세포의 산소 결핍시 새로운 혈관의 형성을 돕는 성장인자 (암에 혈관 을 만들어주는 혈관내피세포형성인자)이며 혈관 생성 표지 (angiogenic marker)의 일종이다. 암세포는 비정상적으로 빠 르게 성장, 분열하므로 많은 영양분과 혈액을 필요로 하고 여 러 가지 물질을 분비하여 신생혈관을 생성하는데, 이 신생혈 관의 형성과 성장을 위해 $\mathrm{VEGF}$ 를 분비한다. $\mathrm{VEGF}$ 는 가장 강력한 혈관형성성장인자로, 혈관내피세포의 증식과 이동을 일으키고 혈관투과성(vascular permeability)을 증진하여 혈 관표피세포에 있는 VEGF receptor와 결합, 활성화되어 암세 포의 혈관생성을 촉진시킨다 ${ }^{28)}$.

본 연구에서 $\mathrm{PH}$ 가 LPS로 유발된 마우스 대식세포의 $\mathrm{VEGF}$ 생성 증가에 미치는 영향을 비교하기 위해 24 시간 동안 처리한 결과 $25 \mu \mathrm{g} / \mathrm{mL}$ 이상의 모든 농도에서 LPS에 의 한 VEGF 생성 증가를 유의하게 억제시켰다.

$\mathrm{PDGF}$ (platelet derived growth factor)-BB는 세포의 성 장과 분화를 조절하는 단백질로서 혈관 형성과 이미 존재하는 혈관 세포로부터의 혈관의 성장에 중요한 역할을 하며 강력한
섬유아세포 분열촉진인자(fibroblast mitogen)이다. 또 $\mathrm{PDGF}$ $-\mathrm{BB}$ 는 $\mathrm{A}$ 부터 $\mathrm{D}$ 까지의 4 가지 isoform을 가지는 것으로 보고 되고 있으며 섬유아세포(fibroblast), 근섬유아세포(myofibroblast), 평활근 세포(smooth muscle cell) 등 간엽 세포(mesenchymal cell)들에 대해 강력한 화학주성을 가지며 세포 분열을 자극하 는 작용을 가지는 것으로 알려져 있다 ${ }^{29)}$. $\mathrm{PDGF}-\mathrm{BB}$ 는 섬유 증식성 질환의 표지로서 결합 조직세포의 한 종류인 섬유아세 포의 세포 분열에 관여하는데 $\mathrm{PDGF}-\mathrm{BB}$ 가 과잉 활성화되면 죽상동맥경화증, 섬유증, 악성질환으로 발전하게 된다 ${ }^{30)}$.

본 연구에서 $\mathrm{PH}$ 가 LPS로 유발된 마우스 대식세포의 $\mathrm{PDGF}-\mathrm{BB}$ 생성 증가에 미치는 영향을 비교하기위해 24 시 간 동안 처리한 결과 $25 \mu \mathrm{g} / \mathrm{mL}$ 이상의 모든 농도에서 LPS에 의한 PDGF-BB 생성 증가를 유의하게 억제시켰다.

$\mathrm{KC}($ Keratinocyte-derived chemokine)는 강력한 호중구 화학유인분자로서 외상을 입으면 $\mathrm{KC}$ 가 호중구의 방출을 매개 하여 대량의 호중구가 혈중에 방출되고 이 호중구는 여러 가 지 염증을 유발한다.

본 실험에서 $\mathrm{PH}$ 가 LPS로 유발된 마우스 대식세포의 $\mathrm{KC}$ 생성 증가에 미치는 영향을 비교하기 위해 24 시간 동안 처 리하였지만 결과에서는 유의한 변화가 나타나지 않았다.

이와같이 본 연구에서 혈관이완인자인 $\mathrm{NO}$ 뿐만 아니라 혈 관신생촉진작용을 하는 $\mathrm{VEGF}, \mathrm{PDGF}-\mathrm{BB}$ 등의 발현조절효 능을 조사하는 것은 염증과 관련된 발암기전에 작용하는 마치 현의 효과를 탐색하는 의미가 있다고 할 수 있을 것이다.

LPS로 유발되는 대식세포 내 칼슘의 생성 증가는 톨라이크리 셉터(Toll-like receptor) 신호전달체계의 활성화와 관련되며, 이는 곧 다양한 염증촉발인자들(proinflammatory mediators) 의 생성 증가로 이어진다 ${ }^{31)}$. 본 연구에서 $\mathrm{PH}$ 가 LPS로 유발 된 마우스 대식세포의 세포내 칼슘 생성 증가에 미치는 영향 을 비교하기위해 24 시간 동안 처리한 결과 $25 \mu \mathrm{g} / \mathrm{mL}$ 이상 의 모든 농도에서 LPS에 의한 세포내 칼슘 생성 증가를 유의 하게 억제시켰다.

이와 같은 결과는 $\mathrm{PH}$ 가 $\mathrm{LPS}$ 에 의해서 증가되는 대식세포 의 칼슘과 $\mathrm{NO}, \mathrm{VEGF}, \mathrm{PDGF}-\mathrm{BB}$ 등의 염증촉발인자 과잉 배출로 인한 종양발생촉진을 완화할 수 있음을 의미한다.

이상의 결과, 馬齒莧을 물추출하여 제조한 시료 $\mathrm{PH}$ 는 대 식세포에 독성을 유발하지 않으면서도 LPS로 유발된 대식세 포의 $\mathrm{NO}, \mathrm{VEGF}, \mathrm{PDGF}-\mathrm{BB}$, 세포내 calcium 생성 증가를 $25,50,100 \mu \mathrm{g} / \mathrm{mL}$ 의 농도에서 유의하게 억제하는 것으로 보아 항염효능을 가지고 있음을 알 수 있었으며, 앞으로 馬齒 莧 물추출물을 이용한 대식세포 관련 염증질환 치료제로의 개 발을 위하여 더욱 많은 연구가 필요할 것으로 사료된다.

\section{결 론}

馬齒莧 물추출물이 mouse macrophage RAW 264.7 cells의 세포생존율과 지질다당체(lipopolysaccharide; LPS)로 유발 된 RAW 264.7 cells의 nitric oxide(NO), vascular endothelial growth factor(VEGF), platelet derived growth factor (PDGF)-BB 등의 염증촉발인자(proinflammatory mediator) 와 세포내 칼슘의 생성 증가에 미치는 영향을 측정하여 다음 과 같은 결과를 얻었다. 
1. 馬齒莧 물추출물을 RAW 264.7과 24 시간 동안 함께 배양한 후 MTT assay를 수행한 결과 $25 \mu \mathrm{g} / \mathrm{mL}$ 이상 의 모든 농도에서 세포의 생존율에 유의한 감소를 나타 내지 않았다.

2. 馬齒莧 물추출물은 LPS에 의해서 유발된 대식세포의 $\mathrm{NO}$ 생성 증가를 $25,50,100 \mathrm{\mu g} / \mathrm{mL}$ 의 농도에서 유의 하게 억제시켰다.

3. 馬齒莧 물추출물은 LPS에 의해서 유발된 대식세포의 $\mathrm{VEGF}$ 생성 증가를 $25,50,100 \mu \mathrm{g} / \mathrm{mL}$ 의 농도에서 유의하게 억제시켰다.

4. 馬齒莧 물추출물은 LPS에 의해서 유발된 대식세포의 $\mathrm{PDGF}-\mathrm{BB}$ 생성 증가를 $25,50,100 \mu \mathrm{g} / \mathrm{mL}$ 의 농도에 서 유의하게 억제시켰다.

5. 馬齒莧 물추출물은 LPS에 의해서 유발된 대식세포의 세포내 calcium의 생성 증가를 $25,50,100 \mu \mathrm{g} / \mathrm{mL}$ 의 농도에서 유의하게 억제시켰다.

이상의 결과, 馬齒莧 물추출물은 대식세포에 독성을 유발 하지 않으면서 LPS로 유발된 대식세포의 NO, VEGF, $\mathrm{PDGF}-\mathrm{BB}$, 세포내 calcium의 생성 증가를 $25 \mu \mathrm{g} / \mathrm{mL}$ 이상 의 농도에서 유의하게 억제하는 등 항염효능을 가지고 있음을 알 수 있었다.

\section{References}

1. Shang ZJ. Xinxiubencao. Hefei : Anhuikexuejishu publisher. $2005:$ 458-9.

2. State Administration of Traditional chiense medicine of the People's Republic of China. Zhonghuabencao. Vol. 5. Shanghai : Shanghai Scientific and Technical Publishers. 1999 : 754-8.

3. Korea Food and Drug Administration. The Korean Herbal Pharmacopoeia IV. Korea Food and Drug Administration. 2012 : 110.

4. Pharmacopoeia Commission of the Democratic People's Republic of Korea Ministry of Health. Democratic People's Republic of Korea Pharmacopoeia 5th edition, Pyongyang : Medical Science Publishers. 1996 : 232-3.

5. The Chinese Pharmacopoeia Commission. Pharmacopoeia of the People's Republic of China 2010. Beijing : China Medical Sciense and Technology Press. 2010 : 46 .

6. Feng PC, Haynes LJ, Magnus KE. High Concentration of (-)-Noradrenaline in Portulaca oleracea L. Nature. $1961 ; 191: 1108$

7. Jiangsuxinyixueyuan. Zhongyaodacidian. Shanghai : Shanghaikexuejishu publisher. 1977 : Shang : 289.

8. Moreau RA, Whitaker BD, Hicks KB. Phytosterols, phytostanols, and their conjugates in foods: structural diversity, quantitative analysis, and health-promoting uses. Prog Lipid Res. 2002 ; 41(6) : 457-500.

9. Bae GH. Hangukui Yakyongsikmul. Seoul : Gyohaksa. 1999 : 97.

10. Cho YJ, Ju IS, Kwon OJ, Chun SS, An BJ, Kim $\mathrm{JH}$. Biological And Antimicrobial Activity of Portulaca oleracea. J Korean Soc Appl Biol Chem. 2008 ; 51(1) : 49-54.

11. Oh KB, Chang IM, Hwang KJ, Mar W. Detection of antifungal activity in Portulaca oleracea by a single-cell bioassay system. Phytother Res. 2000 ; 14(5) : 329-32.

12. Park SH. The Antioxidant Effect of Portulaca oleracea Extracts and Its Antimicrobial Activity on Helicobacter pylori. Keimyung University. 2009.

13. Kim JH. The Inhibitory Effects of Portulaca oleracea L. on $\mathrm{HCl}$-ethanol Induced Gastritis in Rats. Dongshin University. 2009.

14. Kang BS. Anti-inflammatory and anti-oxidative effects of Portulaca oleracea L. extract and fractions. Kyunghee University. 2007.

15. Lim JP, Suh ES. Hepatoprotective, Diuretic and Anti-inflammatory Activities of the Extract from Portulaca oleracea Linne. Korean J Medicinal Crop Sci. 2000 ; 8(3) : 189-93.

16. O OJ. Effects on Cellular and Humoral Immune Responses of Portulacae Herba extract. Sookmyung men's University. 1992.

17. Ferrari M, Fornasieroa MC, Isetta AM. MTT colorimetric assay for testing macrophage cytotoxic activity in vitro. J Immunol Methods. 1990 ; 131(2) : 165-72.

18. Weissman BA, Gross SS. Measurement of NO and NO synthase. Curr Protoc Neurosci. $2001 ; 7$ : 13.

19. Politch JA, Tucker L, Bowman FP, Anderson DJ. Concentrations and significance of cytokines and other immunologic factors in semen of healthy fertile men. Hum Reprod. 2007 ; 22(11) : 2928-35.

20. Paredes RM, Etzler JC, Watts LT, Zheng W, Lechleiter JD. Chemical calcium indicators. Methods. 2008 ; 46(3) : 143-51

21. Shang ZJ. Shiliaobencao. Hefei : Anhuikexuejishu publisher. 2003 : 121.

22. Chen CQ. Bencaoshiyou. Hefei : Anhuikexuejishu publisher. 2002 : 296-7.

23. Su S. Bencaotujing. Hefei : Anhuikexuejishu publisher. 1994 : 591.

24. Lee SJ. Bonchogangmok. Seoul : Uiseongdang. 1993 : 1655 .

25. Heo J. Daeyeokdonguibogam. Seoul : Beopinmunhwasa. 1999 : 1898

26. Teo S, Pohl L, Halpert J. Production of superoxide anion radicals during the oxidative metabolism of 
amino-chloramphenicol. Biochem Pharmacol. 1986 ; 35(24) : 4584-6.

27. Radomski MW, Palmer RM, Moncada S. An Larginine/nitric oxide pathway present in human platelets regulates aggregation. Proc Natl Acad Sci U S A. 1990 ; 87(13) : 5193-7.

28. Holmes K, Roberts OL, Thomas AM, Cross MJ. Vascular endothelial growth factor receptor-2: structure, function, intracellular signalling and therapeutic inhibition. Cellular Signal. 2007 ; 19(10) : 2003-12.

29. Osornio-Vargas AR, Goodell AL, Hernández-Rodríguez NA, Brody AR, Coin PG, Badgett A, Bonner JC. Platelet-derived growth factor(PDGF) $-\mathrm{AA},-\mathrm{AB}$, and $-\mathrm{BB}$ induce differential chemotaxis of early - passage rat lung fibroblasts in vitro. Am $\mathrm{J}$ Respir Cell Mol Biol. 1995 ; 12(1) : 33-40.

30. Gochuico BR, Avila NA, Chow CK, Novero LJ, Wu HP, Ren P, MacDonald SD, Travis WD, Stylianou MP, Rosas IO. Progressive preclinical interstitial lung disease in rheumatoid arthritis. Arch Intern Med. 2008 ; 168(2) : 159-66.

31. Martin L, Pingle SC, Hallam DM, Rybak LP, Ramkumar $\mathrm{V}$. Activation of the adenosine $\mathrm{A}_{3}$ receptor in RAW 264.7 cells inhibits lipopolysaccharide-stimulated Tumor Necrosis factor $-\alpha$ release by reducing calcium-dependent activation of Nuclear Factor$\kappa \mathrm{B}$ and extracellular signal-regulated kinase $1 / 2$. J Pharmacol Exp Ther. 2006 ; 316(1) : 71-8. 